www.jmscr.igmpublication.org

Impact Factor 5.84

Index Copernicus Value: 71.58

ISSN (e)-2347-176x ISSN (p) 2455-0450

crossref DOI: _https://dx.doi.org/10.18535/jmscr/v6i1.134

Journal Of Medical Science And Clinical Research

\title{
Pattern of physical activity and its association with overweight and obesity among rural school going adolescents in Rohtak district, Haryana
}

\author{
Authors \\ Dr B M Vashisht ${ }^{1}$, Dr Vikram. A , Dr Himanshu Bhardwaj $^{3}$ \\ ${ }^{1}$ Professor, Department of Community Medicine, Pt B D Sharma PGIMS, Rohtak \\ ${ }^{2,3}$ Junior Residents, Department of Community Medicine, Pt B D Sharma PGIMS, Rohtak \\ Corresponding Author
}

Dr B M Vashisht

Professor, Department of Community Medicine, Pt B D Sharma PGIMS, Rohtak

Mobile number: 9812176692, Email: drbmvashisht@rediffmail.com

\begin{abstract}
Introduction: Physical activity is one of the major lifestyle-related health determinant. Regular physical activity of moderate intensity - such as walking, cycling, or participation in sports - has significant benefits for health. In today's world, the physical activity, one of the major health-protecting behaviour seems to decline among the adolescents.

Aim and Objectives: To study the pattern of physical activity and its association with overweight and obesity among rural school going adolescents.

Material and Methods: A cross-sectional study was conducted in Lakhanmajra block (rural block) of Rohtak district over a period of one year from July 2016 to June 2017. A total of 750 students from six coeducational government senior secondary schools were included in the study. Data were collected using pre-designed, pre-tested, semi-structured interview schedule and analysed using SPSS version 20.0.

Results: Prevalence of overweight and obesity was $6.7 \%$ and $1.1 \%$ respectively. $10.3 \%$ of the study subjects who were not in the habit of doing any exercises in the morning after getting up were found to be obesel overweight. 13.2\% of the study subjects who did not have the habit of playing daily were obesel overweight. $22 \%$ of the study subjects who used to spend 2-3 hours in a day in idle activities like watching TV or chatting with friends and playing mobile games were obeseloverweight. About one fourth (25.6\%) of the study subjects who were in the habit of sleeping in the afternoon or evening were obeseloverweight. Habit of playing daily, its duration and sleeping in the afternoon/evening were significantly associated with overweight/obesity.

Conclusion: Physical inactivity leads to obesity which in turn gives rise to cardio-vascular diseases and diabetes. Thus, it is the need of the hour to address this problem and devise programs and strategies to prevent overweight and obesity among adolescents. The children should be encouraged for doing physical activity not only for weight control but also for general well-being.
\end{abstract}

Keywords: Physical activity, adolescents, rural, overweight, obesity.

\section{Introduction}

Physical activity is one of the major lifestylerelated health determinant. WHO defines physical activity as any bodily movement produced by skeletal muscles that requires energy expenditure - including activities undertaken while working, 
playing, carrying out household chores, travelling, and engaging in recreational pursuits. ${ }^{1}$

Regular physical activity of moderate intensity such as walking, cycling, or doing sports - has significant benefits for health. It improves muscular and cardiorespiratory fitness, improves bone and functional health and reduces the risk of hypertension, coronary heart disease, stroke, diabetes, various types of cancer (including breast cancer and colon cancer), and depression. ${ }^{1}$

WHO recommends that children and adolescents aged 5-17 years should do at least sixty minutes of moderate to vigorous-intensity physical activity daily.

Physical inactivity has been identified as the fourth leading risk factor for global mortality causing an estimated 3.2 million deaths globally. More than $80 \%$ of the world's adolescents do not perform the recommended physical activity. Insufficient physical activity is a key risk factor for non-communicable diseases (NCDs) such as cardiovascular diseases, cancers and diabetes. ${ }^{1}$

Overweight and obesity are defined as abnormal or excessive fat accumulation that may impair health. The fundamental cause of obesity and overweight is an energy imbalance between calories consumed and calories expended. ${ }^{3}$ Physical inactivity is the main cause of this energy imbalance leading to overweight and obesity. Overweight and obesity are major risk factors for a number of chronic diseases, including diabetes, cardiovascular diseases and cancers.

In today's world, the physical activity which is one of the major health-protecting behaviour is seen to decline among the adolescents. Hence, the present study was conducted to study the pattern of physical activity and its association with overweight and obesity among rural school going adolescents in district Rohtak of Haryana.

\section{Material and Methods}

A cross sectional study was conducted in the community development block Lakhan Majra (district Rohtak), which is a rural field practice area attached to the Department of Community
Medicine, Pt. B. D. Sharma PGIMS, Rohtak over a period of one year from July 2016 to June 2017. The school going adolescents in the age group 1319 years studying in classes 8 th to 12 th in six coeducational government senior secondary schools of Lakhan Majra block formed the study population.

\section{Sample Size}

According to the study conducted by Kowsalya et $\mathrm{al}^{4}$ in Salem district of Tamil Nadu, the prevalence of overweight/obese among school going adolescents was $12.11 \%$. Considering the prevalence as $12.11 \%$, with $95 \%$ confidence interval and allowable error of $20 \%$,

The sample size was thus calculated by using the formula:

$$
\mathrm{n}=\mathrm{( \textrm {Z } _ { 1 - \mathrm { a } / 2 } ) ^ { 2 } \mathrm { X } \text { p X q }}
$$

Sample size came out to be 696 . By assuming a non-response rate of $5 \%$, a sample of 750 eligible subjects was included in the study.

\section{Sampling technique}

The list of all students currently studying from classes $8^{\text {th }}$ to $12^{\text {th }}$ was sought from the Principals of the respective schools. From each school, 125 students were selected. It was proportionate to the strength of eligible students in each class. Simple random sampling technique was used for selection of students from each class through random number generator software.

\section{Inclusion Criteria}

1. Students in the age group 13-19 years studying in classes $8^{\text {th }}-12^{\text {th }}$.

\section{Exclusion Criteria}

1. Students who were not willing to participate in the study.

2. Students who were not present in the respective schools on the days of visit.

\section{Study Instruments}

A pre-designed, pre-tested, semi-structured interview schedule was used to elicit the 
information on socio-demographic profile, time spent on physical activity, hours of sleep and time spent on idle activities like watching TV, sitting and chatting with friends. Anthropometric measurements such as height, weight were recorded and body mass index (BMI) for each student was calculated.

\section{Methodology}

The selected schools were visited in advance and prior permission was sought from the concerned Principals of the respective schools for conducting the study. The students were briefed about the nature and purpose of study and consent forms were distributed to them to get them signed from their parents/guardians. Only those students, who themselves along with their parents consented for the study, were interviewed. The students were interviewed one by one separately and their responses were noted. Confidentiality of the obtained information was maintained.

Study subjects were categorised into underweight, normal, overweight and obese using WHO reference 2007 standards for BMI for boys and girls aged 5-19 years. ${ }^{5,6}$

\section{Data Analysis}

Data collected were compiled, coded appropriately and entered in the MS Excel spread sheet and analysed using statistical package for social sciences (SPSS) software version 20.0. The data were represented as frequency and proportions. Appropriate tests of significance were applied wherever necessary.

\section{Results}

A total of 750 adolescents aged 13-19 years studying in $8^{\text {th }}-12^{\text {th }}$ classes were included in the study. The majority $(60.7 \%)$ of the study subjects were in the age group 15-17 years followed by $13-14$ years $(31.1 \%)$ and $18-19$ years $(8.2 \%)$. The mean age of the study subjects was $15.38 \pm 1.493$ years.

Majority (24.4\%) of the study subjects belonged to $10^{\text {th }}$ class followed by $9^{\text {th }}(20.9 \%), 11^{\text {th }}(20 \%)$, $12^{\text {th }}(18.3 \%)$ and $8^{\text {th }}(16.4 \%)$ classes. $61.7 \%$ of the study subjects belonged to Nuclear families followed by Joint families $(20.5 \%)$ and Three generation families (17.8\%) respectively. More than half $(54.7 \%)$ of the study subjects had upto5 members in the family followed by $44.7 \%$ with 6 - 10 family members and only very few $(0.6 \%)$ had more than 10 family members. $38.3 \%$ of the study subjects had monthly family income between 10,000 to 15,000 rupees followed by $30.7 \%$ with income less than 10,000 rupees and $19.8 \%, 11.2 \%$ belonging to income range more than 15,000 to 20,000 rupees and more than 20,000 rupees respectively.

Table 1: Distribution of study subjects according to physical activity $(n=750)$

\begin{tabular}{|c|c|c|c|}
\hline \multicolumn{2}{|l|}{ Characteristic } & Frequency & Percentage \\
\hline \multirow{2}{*}{$\begin{array}{ll}\begin{array}{l}\text { Regular } \\
\text { exercise }\end{array} & \text { morning } \\
\end{array}$} & Yes & 243 & 32.4 \\
\hline & No & 507 & 67.6 \\
\hline \multirow{3}{*}{$\begin{array}{l}\text { Type of exercise } \\
(n=243)\end{array}$} & Stretching & 100 & 41.15 \\
\hline & Yoga & 100 & 41.15 \\
\hline & Jogging/Walking & 43 & 17.70 \\
\hline \multirow{3}{*}{$\begin{array}{l}\text { Distance of school } \\
\text { from home }\end{array}$} & Less than $2 \mathrm{Km}$ & 546 & 72.8 \\
\hline & $2-4 \mathrm{Km}$ & 182 & 24.3 \\
\hline & More than $4 \mathrm{Km}$ & 22 & 2.9 \\
\hline \multirow[t]{3}{*}{ Mode of transport } & On foot & 588 & 78.4 \\
\hline & Bicycle & 160 & 21.3 \\
\hline & Others & 2 & 0.3 \\
\hline \multirow{3}{*}{$\begin{array}{l}\text { Time taken for } \\
\text { commuting to school } \\
\text { and back home }\end{array}$} & $\begin{array}{l}\text { Less than } 20 \\
\text { mins }\end{array}$ & 494 & 65.9 \\
\hline & $20-40$ mins & 225 & 30.0 \\
\hline & $\begin{array}{l}\text { More than } 40 \\
\text { mins }\end{array}$ & 31 & 4.1 \\
\hline \multirow[t]{2}{*}{ Habit of playing daily } & Yes & 454 & 60.5 \\
\hline & No & 296 & 39.5 \\
\hline \multirow{4}{*}{ Games played $(n=454)$} & Cricket & 179 & 39.43 \\
\hline & Kabbadi & 116 & 25.56 \\
\hline & Football & 89 & 19.60 \\
\hline & Others & 70 & 15.41 \\
\hline \multirow{3}{*}{ Duration of Playing } & Less than 1 hour & 216 & 28.8 \\
\hline & 1-2 hours & 224 & 29.9 \\
\hline & $\begin{array}{l}\text { More than } 2 \\
\text { hours }\end{array}$ & 14 & 1.8 \\
\hline \multirow{3}{*}{$\begin{array}{l}\text { Total time spent in a } \\
\text { day in idle activities } \\
\text { like watching TV, } \\
\text { playing mobile games } \\
\text { and talking to friends }\end{array}$} & $\begin{array}{l}\begin{array}{l}\text { Less } \\
\text { hours }\end{array} \\
\text { than }\end{array}$ & 535 & 71.3 \\
\hline & 2-3 hours & 200 & 26.7 \\
\hline & $\begin{array}{l}\text { More than } 3 \\
\text { hours }\end{array}$ & 15 & 2 \\
\hline
\end{tabular}

Table 1 shows the distribution of study subjects according to various types of physical activities performed. About one third (32.4\%) of the study subjects had the habit of doing exercise in the morning after getting up. Among the exercise, yoga $(41.15 \%)$ and simple stretching exercises $(41.15 \%)$ were commonly done in the morning. 
$72.8 \%$ of the study subjects had their school situated at a distance of less than $2 \mathrm{Km}$ from their homes followed by $24.3 \%$ situated between 2-4 $\mathrm{Km}$ and only a few (2.9\%) had their school situated at distance more than $4 \mathrm{Km}$. More than three fourth $(78.4 \%)$ of the study subjects walked to their school from home and $21.3 \%$ used a bicycle to commute to school. $65.9 \%$ of the study subjects took less than 20 minutes, $30 \%$ took 20 40 minutes and only $4.1 \%$ took more than 40 minutes for commuting between home to school and back.

Majority (60.5\%) of the study subjects had the habit of playing daily. Cricket $(39.43 \%)$ and Kabbadi (25.56\%) were the most commonly played games by the study subjects.

$29.9 \%$ of the study subjects played for 1-2 hours per day and $28.8 \%$ played for less than one hour per day. Only $1.8 \%$ study subjects played for more than two hours per day.

Majority (71.3\%) of the study subjects spent less than two hours in a usual day watching TV/playing mobile games or sitting and chatting with friends. $26.7 \%$ spent $2-3$ hours and only $2 \%$ spent more than 3 hours for these idle activities.
Table 2: Distribution of study subjects according to sleep pattern $(n=750)$

\begin{tabular}{|l|l|c|c|}
\hline \multicolumn{2}{|l|}{} & Frequency & Percentage \\
\hline $\begin{array}{l}\text { Habit of sleeping } \\
\text { in } \\
\text { afternoon/evening }\end{array}$ & Yes & 176 & 23.5 \\
\cline { 2 - 4 } & No & 574 & 76.5 \\
\hline $\begin{array}{l}\text { Hours of sleep } \\
\text { per day }\end{array}$ & Less than 6 hours & 11 & 1.5 \\
\cline { 2 - 4 } & $\mathbf{6 - 8}$ hours & 559 & 74.5 \\
\cline { 2 - 4 } & $\mathbf{8}-10$ hours & 173 & 23.1 \\
\cline { 2 - 4 } & More than10 hours & 7 & 0.9 \\
\hline
\end{tabular}

Almost one fourth $(23.5 \%)$ of the total study subjects had the habit of sleeping in the afternoon or evening. Around three fourth of the subjects (74.5\%) had sleep for 6-8 hours per day followed by $23.1 \%$ who slept for $8-10$ hours per day and $1.5 \% \& 0.9 \%$ with sleep duration of less than 6 hours and more than 10 hours per day respectively. (Table 2)

Table 3: Distribution of study subjects according to WHO BMI cut off values

\begin{tabular}{|l|c|c|}
\hline Category & Frequency & Percentage \\
\hline Underweight & 67 & 8.9 \\
\hline Normal & 625 & 83.3 \\
\hline Overweight & 50 & 6.7 \\
\hline Obese & 8 & 1.1 \\
\hline Total & 750 & 100 \\
\hline
\end{tabular}

Table 3 shows that $6.7 \%$ and $1.1 \%$ of the study subjects were overweight and obese respectively.

Table 4: Association of obesity/overweight with physical activity

\begin{tabular}{|c|c|c|c|c|c|c|c|c|}
\hline & & \multicolumn{4}{|c|}{ Obese/Overweight } & \multirow[b]{3}{*}{$\chi^{2}$ value } & \multirow[b]{3}{*}{ df } & \multirow[b]{3}{*}{ p value } \\
\hline & & \multicolumn{2}{|c|}{ Yes } & \multicolumn{2}{|c|}{ No } & & & \\
\hline & & Freq & $\%$ & Freq & $\%$ & & & \\
\hline \multirow[t]{2}{*}{ Regular morning exercise } & No & 52 & 10.3 & 455 & 89.7 & \multirow[t]{5}{*}{13.96087} & \multirow[t]{2}{*}{1} & \multirow[t]{2}{*}{$0.000^{*}$} \\
\hline & Yes & 6 & 2.5 & 237 & 97.5 & & & \\
\hline \multirow{3}{*}{$\begin{array}{l}\text { Mode of transport to go } \\
\text { to school }\end{array}$} & On foot & 43 & 7.3 & 545 & 92.7 & & & \multirow[t]{3}{*}{0.093} \\
\hline & Bicycle & 15 & 9.4 & 145 & 90.6 & & & \\
\hline & Others & 0 & 0 & 2 & 100 & & & \\
\hline \multirow[t]{2}{*}{ Habit of playing daily } & No & 39 & 13.2 & 257 & 86.8 & \multirow[t]{2}{*}{20.298} & \multirow[t]{2}{*}{1} & \multirow[t]{2}{*}{$0.000^{*}$} \\
\hline & Yes & 19 & 4.2 & 435 & 95.8 & & & \\
\hline \multirow[t]{4}{*}{ Duration of playing } & NA & 39 & 13.2 & 257 & 86.8 & \multirow[t]{4}{*}{24.06585} & \multirow[t]{4}{*}{3} & \multirow[t]{4}{*}{$0.000^{*}$} \\
\hline & $<1$ hour & 12 & 5.6 & 204 & 94.4 & & & \\
\hline & 1-2 hours & 5 & 2.2 & 219 & 97.8 & & & \\
\hline & $>2$ hours & 2 & 14.3 & 12 & 85.7 & & & \\
\hline \multirow{3}{*}{$\begin{array}{l}\text { Total time spent in a day } \\
\text { watching } T V \text {, playing mobile } \\
\text { games, talking to friends }\end{array}$} & $<2 \mathrm{hrs}$ & 13 & 2.4 & 522 & 97.6 & 78.16392 & 2 & $0.001^{*}$ \\
\hline & $2-3 \mathrm{hrs}$ & 44 & 22 & 156 & 78 & & & \\
\hline & $>3$ hours & 1 & 6.7 & 14 & 93.3 & & & \\
\hline
\end{tabular}

Table 4 shows the association of obesity/ overweight with physical activity of study subjects. Approximately one-tenth (10.3\%) of the study subjects who were not in the habit of doing any exercise in the morning were found to be obese/overweight, whereas, only very few $(2.5 \%)$ the habit of doing exercise in the morning. This finding was statistically significant.

Regarding the mode of transport to school, 9.4\% of the study subjects who used bicycle to commute to school were obese/overweight in comparison to those who walked to school $(7.3 \%)$. were obese/overweight among those who were in 
However, this finding was statistically notsignificant.

$13.2 \%$ of the study subjects who were not playing daily were obese/overweight as compared to those who were in the habit of playing daily $(4.2 \%)$. When the duration of playing was considered, the number of obese/overweight study subjects decreased with increase in duration of playing. This finding was statistically significant.
$22 \%$ of the study subjects who used to spend 2-3 hours in a day in idle activities like watching TV or chatting with friends or playing mobile games were obese/overweight. $6.7 \%$ and $2.4 \%$ of the study subjects who spent more than 3 hours and less than 2 hours in idle activities were obese/overweight. This finding was statistically significant.

Table 5: Association of obesity/overweight with sleep pattern

\begin{tabular}{|c|c|c|c|c|c|c|c|c|}
\hline & & \multicolumn{4}{|c|}{ Obese/Overweight } & \multirow[b]{3}{*}{$\chi^{2}$ value } & \multirow[b]{3}{*}{ df } & \multirow[b]{3}{*}{ p value } \\
\hline & & \multicolumn{2}{|c|}{ Yes } & \multicolumn{2}{|c|}{ No } & & & \\
\hline & & Freq & $\%$ & Freq & $\%$ & & & \\
\hline \multirow{2}{*}{$\begin{array}{l}\text { Sleeping in } \\
\text { afternoon/evening }\end{array}$} & No & 13 & 2.3 & 561 & 97.7 & \multirow[t]{2}{*}{102.5155} & \multirow[t]{2}{*}{1} & \multirow[t]{2}{*}{$0.000^{*}$} \\
\hline & Yes & 45 & 25.6 & 131 & 74.4 & & & \\
\hline \multirow{4}{*}{$\begin{array}{l}\text { Hours of } \\
\text { per day }\end{array}$} & $<6$ & 0 & 0 & 11 & 100 & & \multirow[t]{4}{*}{3} & \multirow[t]{4}{*}{$0.001^{*}$} \\
\hline & $6-8$ & 26 & 4.7 & 533 & 95.3 & & & \\
\hline & $8-10$ & 31 & 17.9 & 142 & 82.1 & & & \\
\hline & $>10$ & 1 & 14.3 & 6 & 85.7 & & & \\
\hline
\end{tabular}

Table 5 shows the association of obesity/ overweight with sleep pattern of study subjects. About one fourth $(25.6 \%)$ of the study subjects who were in the habit of sleeping in the afternoon or evening were obese/overweight, whereas, only $2.3 \%$ of those who did not have this habit were obese/overweight. The prevalence of obesity/ overweight was also higher (17.9\%) among study subjects who had sleep for 8-10 hours as against $14.3 \%$ for those having sleep for more than 10 hours in a day. This finding was statistically significant.

\section{Discussion}

The present study included 750 school going adolescents aged 13-19 years studying in classes $8^{\text {th }}-12^{\text {th }}$ in Govt. Sr. Sec Schools of Lakhan Majra block of Rohtak district. Out of the total study subjects, majority $(60.7 \%)$ were in the age group 15-17 years. Males $(72.5 \%)$ outnumbered the females $(27.5 \%) .24 .4 \%$ of the study subjects belonged to class $10^{\text {th }}$ followed by $20.9 \%$ belonging to $9^{\text {th }}$ class. $61.7 \%$ of the study subjects belonged to nuclear family. More than half $(54.7 \%)$ of the study subjects had 5 and less than 5 family members. $38.3 \%$ of the study subjects had monthly family income between 10.000 to 15,000 rupees followed by $30.7 \%$ with monthly income less than 10,000 rupees.

\section{Prevalence of overweight and obesity}

In the present study, prevalence of overweight and obesity was found to be $6.7 \%$ and $1.1 \%$ respectively (Table 3) among rural school going adolescents of Rohtak district, Haryana. Similar prevalence of overweight $(6.6 \%)$ and obesity (1.1\%) was observed in the study conducted by Tiwari et $\mathrm{al}^{7}$ in Allahabad in which WHO BMI cut off values were used to categorize the study subjects as overweight and obese.

Higher prevalence of overweight and obesity were reported in studies conducted by Choudhary et al ${ }^{8}$ in Patna $(6.3 \%$ obese and $10.3 \%$ overweight), Prajapati et $\mathrm{al}^{9}$ in Vidarbha $(11.8 \%$ obese and $15.8 \%$ overweight). This may be because studies were conducted in different areas and included different age groups.

A study conducted by Mithra et $\mathrm{al}^{10}$ in Udupi district of Karnataka reported prevalence of overweight and obesity to be $2.4 \%$ and $1.4 \%$. This was much lower in comparison to the present study. The reason may be attributed to larger sample size (2963 students) and inclusion of students belonging to age group $10-18$ years. 


\section{Overweight/obesity and physical activity}

According to WHO, global recommendations on physical activity for health ${ }^{2}$ the cumulative moderate to vigorous physical activity done by children and adolescents aged 5- 17 years should be at least 60 minutes daily. Only $31.7 \%$ children studied had the recommended level of physical activity. This finding was comparable to the report of India Global School Based Health Survey (GSHS) $^{11} 2007$ conducted by CBSE, where 30.2\% of the students were physically active for at least 60 minutes per day on all days in the last week.

Higher (13.2\%) proportion of the study subjects who did not have the habit of playing daily were overweight/obese in comparison to those who were in the habit of playing daily (4.2\%). When the duration of playing was considered, the number of overweight/obese students decreased with increase in the duration. This finding was statistically significant.

Similar findings were reported in the studies conducted by Tiwari et $\mathrm{al}^{7}$, Kumar et $\mathrm{al}^{12}$ and Choudhary et $\mathrm{al}^{8}$ where the prevalence of overweight/obesity was higher in students who did not do any physical activity/played outdoor games as compared to those who played daily. These findings can be explained by the fact that lack of physical activity causes energy imbalance and leads to overweight/obesity.

$22 \%$ of the students who spent two to three hours per day in idle activities like watching TV, playing mobile games and chatting with friends were found to be overweight/obese in the present study. This finding was statistically significant. Similar findings were reported by Kumar et $\mathrm{al}^{12}$, Choudhary et $\mathrm{al}^{8}$, Prajapati et $\mathrm{al}^{9}$ and Watharkar et $\mathrm{al}^{13}$ in their studies, where the prevalence of overweight/obesity among students who watched TV/played mobile games for more than two hours was higher as compared to those who watched TV/played mobile games for less than two hours. Parents preferred their children to sit and watch TV at home where they could keep an eye on them rather than allowing them to play outside unattended. This again led to energy imbalance and finally overweight/obesity.

\section{Overweight/obesity and sleeping pattern}

About one fourth $(25.6 \%)$ of the participants who were in the habit of sleeping in the afternoon/evening were overweight/obese compared with those who did not have this habit $(2.3 \%)$. This was consistent with the findings of the study conducted by Watharkar et $\mathrm{al}^{13}$, in which $31.1 \%$ of the study subjects who had the habit of sleeping in the afternoon were overweight/obese as compared to those who did not sleep in the afternoon (8.6\%).

The present study also found higher $(17.9 \%$ \& $14.3 \%$ ) prevalence of overweight/obesity among study subjects who slept for 8-10 hours per day and more than 10 hours per day as compared to those who had normal sleep duration (6-8 hours per day - $4.7 \%$ ). Sleeping burns less calories as compared to physical activity thus causes energy imbalance and overweight/obesity.

\section{Conclusion}

The prevalence of overweight and obesity among adolescents is on an increasing trend in rural areas. Habit of playing daily, its duration, and the habit of sleeping in the afternoon/evening were significantly associated with the overweight /obesity. As stated earlier, physical inactivity leads to obesity which in turn gives rise to cardiovascular diseases and diabetes. Thus, it is the need of the hour to address this problem and devise programs and strategies to prevent overweight and obesity among adolescents.

\section{Recommendations}

The children should be encouraged to be physically active not only for weight control but also for general well-being. A moderate to vigorous physical activity for a period of at least one hour per day will be a more practical thing for all school going children. The schools should have adequate space and facilities for students to spend their free time actively. The sports and physical training activities should be inbuilt in school 
curriculum. The physical activity should become their way of life. The school should look after all aspects of health of the children which includes physical, mental and social well-being. The group physical activities take care of all these things.

\section{Reference}

1. World Health Organization. Physical activity fact sheet [Internet]. Geneva: World Health Organization;2017 [updated 2017 Feb; cited 2018 Jan 07]. Available from:

http://www.who.int/mediacentre/factsheets /fs385/en/

2. World Health Organization. Global recommendations on physical activity for health [Internet].Geneva:World Health Organization;2010 [cited 2018 Jan 07]. Available form: http://whqlibdoc.who.int/publications/201 0/9789241599979_eng.pdf

3. World Health Organization. Obesity and Overweight, Fact sheet [Internet]. Geneva: World Health Organization; 2016 [cited 2018 Jan 07]. Available from: http://www.who.int/mediacentre/factsheets /fs311/en/

4. Kowsalya T, Parimalavalli R. Prevalence of overweight/obesity among adolescents in urban and rural areas of Salem, India. J Obes Metab Res [Internet]. 2014 [cited 2018 Jan 07];1(3):152-5. Available form: http://www.jomrjournal.org/temp/JObesM etabRes13152-1043109_025351.pdf

5. World Health Organization. BMI - for age GIRLS 5 -19 years (percentiles) [Internet]. Geneva: World Health Organization. 2007 [cited 2018 Jan 07]. Available from: http://www.who.int/growthref/bmifa_girls _5_19years_per.pdf?ua $=1$

6. World Health Organization. BMI - for age BOYS 5 -19 years (percentiles) [Internet]. Geneva: World Health Organization. 2007 [cited 2018 Jan 07].
Available

from:

http://www.who.int/growthref/bmifa_boys _5_19years_per.pdf?ua=1

7. Tiwari HC, Dwivedi S, Bali S, Parveen K. Overweight \& obesity and it's correlates among school going adolescents of district Allahabad- a cross sectional study. Indian J Prev Soc Med [Internet]. 2014 [cited 2018 Jan 07];45(2):77-82. Available from: http://medind.nic.in/ibl/t14/i1/iblt14i1p77. pdf

8. Choudhary SK, Kumar S, Bharati DR, Rajak BK, Kumari S, Shree V. Problem of Obesity among School Going Adolescent in Rural Practice Area of Indira Gandhi Institute of Medical Sciences, Patna. Int J Sci Stud [Internet]. 2017 [cited 2018 Jan 07];5(3):102-7. Available from: http://dx.doi.org/10.17354/ijss/2017/276

9. Prajapati K, Nayak S, Dhande N, Mudey A. Prevalence of overweight and obesity among rural early adolescents in central part of Vidarbha, Maharashtra- A Cross Sectional study. Int $\mathrm{J}$ Med Res Rev [Internet].2017 [cited 2018 Jan 07];5(07):725-30. Available from: http://medresearch.in/index.php/IJMRR/art icle/view/1880/2877

10. Mithra PP, Kumar P, Kamath VG, Kamath A, Unnikrishnan B, Rekha $\mathrm{T}$, et al. Lifestyle factors and obesity among adolescents in rural south India. Asian J Pharm Clin Res [Internet].2015 [cited 2018 Jan 07];8(6):81-3. Available from: https://innovareacademics.in/journals/inde x.php/ajpcr/article/view/7513/3388

11. World Health Organization. Chronic disease and health promotion, Global School based Student Health Survey (GSHS), Country Factsheets, India [Internet]. Geneva: World Health Organization; 2007 [cited 2018 Jan 07]. Available from: http://www.who.int/entity/chp/gshs/factshe ets/en/index.html. 
12. Kumar KM, Prashanth K, Baby KE, Rao $\mathrm{KR}$, Kumarkrishna B, Hegde $\mathrm{K}$, et al. Prevalence of obesity among high school children in Dakshinakannada and Udupi districts. Nitte University Journal of Health Sciences. 2011;1(4):16-20.

13. Watharkar A, Nigam S, Martolia DS, Varma P, Barman SK, Sharma RP. Assessment of risk factors for overweight and obesity among school going children in Kanpur, Uttar Pradesh. Indian J Comm Health [Internet]. 2015 [cited 2018 Jan 07]; 27(2): 216 - 222. Available form: http://www.iapsmupuk.org/journal/index.p hp/IJCH/article/view/883/704 